\title{
Chondracanthid copepod parasites of dories (Zeiformes: Zeidae) with the description of a new species of Chondracanthus from waters off northern Argentina
}

\author{
Paola E. Braicovich ${ }^{1}$, Ana L. Lanfranchi ${ }^{1}$, Inés S. Incorvaia ${ }^{2}$ and Juan T. Timi ${ }^{1}$ \\ ${ }^{1}$ Laboratorio de Parasitología, Instituto de Investigaciones Marinas y Costeras, Universidad Nacional de Mar del Plata-CONICET, \\ Mar del Plata, Argentina; \\ ${ }^{2}$ Laboratorio de Parasitología, Instituto Nacional de Investigaciones y Desarrollo Pesquero, Mar del Plata, Argentina
}

\begin{abstract}
A new species of parasitic copepod, Chondracanthus hoi sp. n. (Copepoda: Chondracanthidae), is described based on specimens of both sexes collected from the buccal cavity and gill arches of the silvery john dory, Zenopsis conchifer (Lowe) (Zeiformes: Zeidae), from waters off northern Argentina $\left(35-36^{\circ} \mathrm{S}, 53-54^{\circ} \mathrm{W}\right)$. Female of $C$. hoi differs from its congeners by the following combination of characters: presence of five pairs of trunk processes, antennule with four knobs tipped with small setae and absence of denticles on the terminal process of maxilla. Chondracanthids and zeiform fishes have been proposed as an example of co-speciation; this assumption is derived from a series of analyses based on incomplete records of both geographical distribution and host range of some parasite species, as well as misidentification of fish hosts. These inconsistences observed during our bibliographical analyses are also discussed.
\end{abstract}

Keywords: Copepoda, taxonomy, South America, zeids, marine fish, host range, zoogeographical distribution

The genus Zenopsis Gill (Zeiformes: Zeidae) consists of four species (Nakabo et al. 2006, Santini et al. 2006); one of them, the silvery john dory, Z. conchifer (Lowe), occurs in the Atlantic and Indian Oceans (Froese and Pauly 2012). In the western Atlantic its distribution ranges from Nova Scotia to North Carolina (Scott and Scott 1988) and from Brazil (Haimovici et al. 1994) to northern Argentina (Quigley and Flannery 1995).

During a parasitological survey of $Z$. conchifer carried out from the southernmost boundary of its distribution in the south-western Atlantic, the northern Argentine Sea, copepods belonging to the genus Chondracanthus Delaroche, 1811 were found.

At present, a total of 39 species of Chondracanthus are considered valid (Tang et al. 2007); among them is a group of four species, namely $C$. polymixiae Yamaguti, 1939, C. shiinoi (Shiino, 1955), C. distortus Wilson, 1922 and C. zei Delaroche, 1811, parasitizing zeiform fishes (Ho 1991, Paterson and Poulin 1999). Two of them, $C$. distortus and C. zei, have been reported as parasites of members of the genus Zenopsis. Chondracanthus distortus was recorded on Z. nebulosa (Temminck and Schlegel) from Japan (Yamaguti 1939) and C. zei from Z. conchifer from Angola (Capart 1959). The copepods found in Z. conchifer from Argentina represent a new species, which is described herein.
Chondracanthids and zeiforms have been proposed as a clear example of host-parasite co-speciation (Ho 1991, Paterson and Poulin 1999). These conclusions, however, were derived from a series of analyses based on incomplete records of both geographical distribution and host range of some parasite species, as well as from misidentification of fish hosts. These inconsistencies are also discussed.

\section{MATERIALS AND METHODS}

A total of eight specimens of Zenopsis conchifer, caught during a research cruise at the northern Argentine Sea $\left(35-36^{\circ} \mathrm{S}\right.$, $53-54^{\circ} \mathrm{W}$ ) in October 2011, were examined for parasites. Copepods were removed from the buccal cavity and gill rakers, fixed in $10 \%$ formaldehyde solution and then transferred to $70 \%$ ethanol for storage until ready to be studied and measured. A subsample of four adult specimens was cleared in lactic acid; the appendages were dissected and examined under a light microscope. Illustrations were drawn with the aid of a drawing tube.

All measurements were based on all specimens examined and given in millimetres $(\mathrm{mm})$ with ranges in parentheses, unless otherwise indicated. The terms prevalence and mean intensity of infection were used according to Bush et al. (1997).

The type material is deposited in the Carcinological Collection of the Museo de La Plata, La Plata, Argentina and in the Institute of Parasitology, Biology Centre of the Academy of Sciences of the Czech Republic, České Budějovice, Czech Republic. 


\section{RESULTS}

Chondracanthus hoi sp. n.

Figs. 1-28

Diagnosis (based on 11 ovigerous females and three males).

Female (Figs. 1-15): Body divided into head, short neck and stout trunk (Figs. 1-3). Total body length (from anterior margin of head to distal end of posterior processes on trunk) 5.6 (3.4-7.1). Head composed of cephalosome only, slightly wider than long, 1.5 (1.1-1.8) long, 1.7 (1.5-2.0) wide, with two pairs of blunt, pedunculate lateral processes, bearing medial longitudinal sclerotized bar and rounded dorsal swelling (visible in lateral view). Neck region composed of first pediger only, narrow, 0.3 (0.06-0.5) long. Remaining pedigers fused into trunk, 3.8 (2.0-4.8) long, including posterior processes. Second pediger $2.3(1.5-2.8)$ wide, with distinct anterolateral shoulders and one pair of robust lateral processes projecting from antero-lateral corners. In three specimens (one adult and two juvenile females) first pair of lateral processes bearing ventrolateral stump.

Remaining thoracic segments fused, 2.6 (1.4-3.1) wide, distinguished from second pediger by lateral indentation visible in dorsal view and armed with four pairs of processes: ventral pair of smaller processes flanking junction of trunk with genito-abdomen and three pairs of longer lateral processes, second pair bifurcate; additional median processes arising from dorsal side of trunk; all extending beyond distal limit of genito-abdomen. Abdomen globular, small, broadly fused with genital complex (Fig. 4), carrying pair of dorsal setules. Caudal ramus conical, directed ventrally and armed with two ventral setae, one dorsal seta and apical conical spinulose papilla (Fig. 5). Eggs sac cylindrical and irregularly coiled, multiseriate.

Antennule (Fig. 6) unsegmented, distinctly separated into large fleshy base with five knobs in ventral side (four basal ones bearing small seta, distal one naked) and narrower tip, armed with ten elements: two ventrolateral setae (one basal and other medial), one dorsal medial short seta and tipped with six long naked setae and one short seta (Fig. 6). Antenna (Fig. 7) two-segmented; basal segment unarmed; terminal segment heavily sclerotized consisting of curved claw with sharply pointed tip, marked by band of transverse surface striations near tip. Labrum (Fig. 8) with smooth posterior surface and small knobs on lateral margins. Mandible (Fig. 9) two-segmented, with 114-116 teeth on convex margin and 74-84 teeth on concave margin of terminal falcate process.

Paragnath a small fleshy lobe armed distally with diminutive spinules (Fig. 10). Maxillule (Fig. 11) lobate, tipped with two unequal apical elements and two lateral small knobs. Maxilla (Fig. 12) two-segmented; first segment squat and unarmed; terminal segment claw-like, armed with row of 11-16 denticles, and two basal setae. Maxilliped (Fig. 13) three-segmented; first segment ro- bust and unarmed; second segment with lobate distal end bearing patches of minute spinules on inner edge; terminal segment small, claw-like, with one denticle at distal third of concave side. Two pairs of biramous legs present. Left leg 1 (Fig. 14) 0.7 (0.6-1.0) long, slightly longer than right leg 1, $0.6(0.4-0.7)$ long. Legs 2 rami (Fig. 15) similar in size with each other, right leg $0.6(0.4-0.7)$ long, left leg $0.6(0.4-0.7)$ long, situated ventrally on trunk region. Each leg with protopod bearing outer seta and exopod ornamented with dispersed minute spinules.

Male (Figs. 16-28): Body (Fig. 16) divided into globose cephalothorax and ventrally flexed genito-abdomen, $0.6(0.5-0.7)$ long, $0.3(0.3-0.3)$ maximum width; metamerism of body indistinct. Main body flexure located between pediger 1 and 2. Genital complex (Fig. 17) with pair of ventral ridges representing opercula of genital apertures. Abdomen broadly fused with genital complex and indistinct. Caudal ramus (Fig. 18) with short spiniform accessory branch dorsal to spinulate terminal process and three setae on basal portion, one dorsal and two ventral.

Antennule (Fig. 19) cylindrical, unsegmented, with armature of two proximo-lateral setae, two subterminal setae and six apical setae. Antenna (Fig. 20) two-segmented, basal segment unarmed, terminal recurved hook with accessory antennule reduced to three spine-like elements on ventrolateral surface and one ventral spine. Labrum (Fig. 21) naked with rounded median knob. Mandible (Fig. 22) two-segmented, with 23-26 teeth on convex margin and 15 teeth on concave margin of terminal blade.

Paragnath lobate, naked (Fig. 23). Maxillule (Fig. 24) lobate bearing two terminal unequal elements. Maxilla (Fig. 25) robust, bearing two setae, terminal process with 6-8 teeth. Maxilliped (Fig. 26) three-segmented, first segment naked; second segment bearing patch of denticles on inner-distal surfaces; terminal segment ending in curved claw-like structure bearing hooklet on distal inner surface. Legs small, leg 1 (Fig. 27) and leg 2 (Fig. 28) similar in size; with protopod bearing one long outer seta; endopod reduced; exopod tipped with one seta.

Type host: Silvery john dory, Zenopsis conchifer (Lowe) (Zeiformes: Zeidae).

Site of infection: Gill rakers and deeper part of bucal roof.

Type locality: Coastal zone of Buenos Aires Province, Argentina $\left(35-36^{\circ} \mathrm{S}, 53-54^{\circ} \mathrm{W}\right)$.

Date of collection: October 2011.

Prevalence: $88 \%$ (7 fishes infected out of 8 fishes examined).

Mean intensity (range): $2.9(1-7)$.

Specimens deposited: Holotype No. 26.861 (female), allotype No. 26.862 (male), and paratypes ( 2 females with attached male) No. 26.863 are deposited in the Carcinological Collection of the Museo de La Plata (CCMLP), La Plata, Argentina. Two additional paratypes are deposited in the Institute of Parasitology, České Budějovice, Czech Republic (Cat. No. Cr-14). 


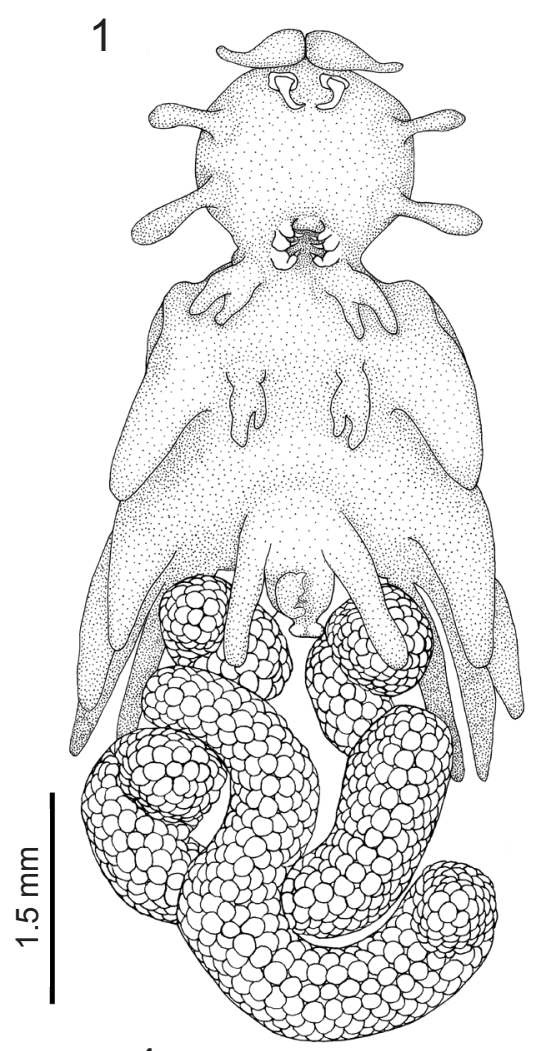

4
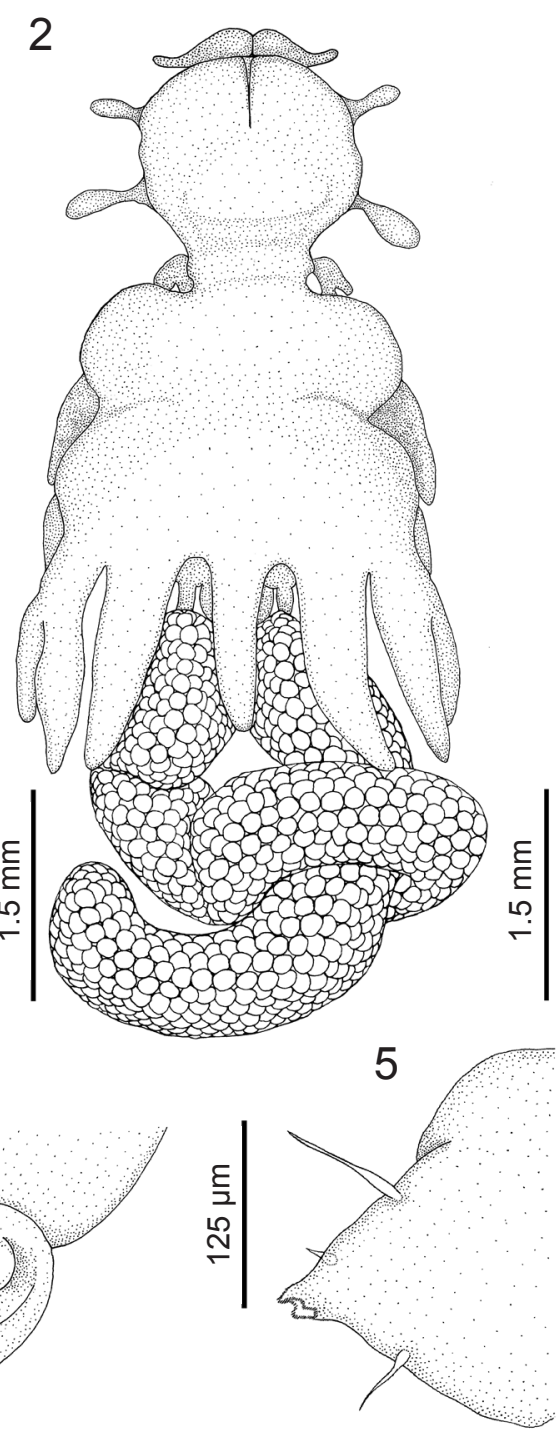

3

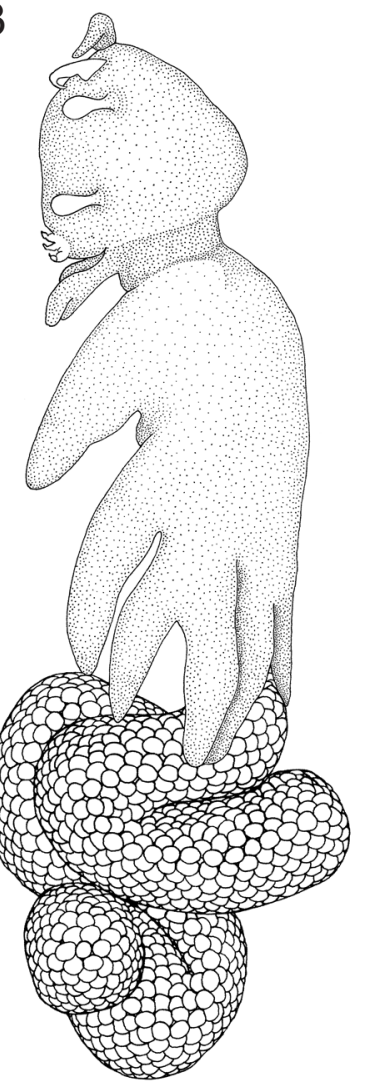

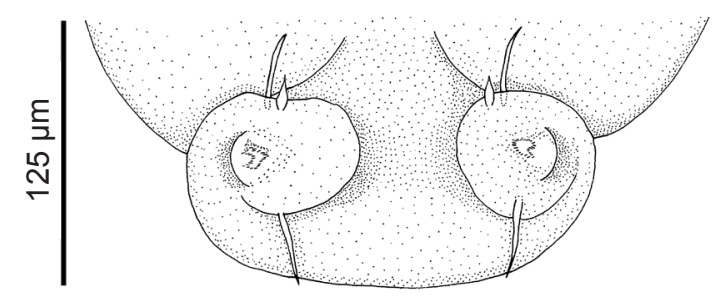

Figs. 1-5. Chondracanthus hoi sp. n., female. Fig. 1. Habitus, ventral view. Fig. 2. Habitus, dorsal view. Fig. 3. Habitus, lateral view. Fig. 4. Genito-abdomen, ventral view. Fig. 5. Caudal ramus, ventral view.

E ty m o log y: This species is named in honour of Dr. Ju-Shey Ho for his vast and invaluable work on parasitic copepods in general and on chondracanthids in particular.

Remarks. According to the last available key to species of Chondracanthus provided by Tang et al. (2007), by having legs 1 and 2 bilobate, the trunk region without outgrowths on the mid-dorsal surface and bearing more than two pairs of lateral processes, the head with two pairs of lateral processes and the abdomen not extended posteriorly, the new species closely resembles $C$. distortus, which may be related due the phylogenetic relatedness of their fish hosts, i.e. zeids. This copepod species was described from Zeus faber Linnaeus (as Z. japonicus Valeciennes) and subsequently redescribed by Shiino (1955) based on specimens from $Z$. nebulosa.

However, C. hoi sp. n. can be distinguished from C. distortus by differences in the number and shape of proccess of the second pediger, with only one robust pair of processes present in the new species (instead of three in $C$. distortus), by the armature of the antenule (several terminal setae and a subterminal one on the posterior posterior margin - Yamaguti 1939) and the absence of a patch of denticles on the terminal process of the female maxilla as described by Ho (1975). In addition, the male of C. hoi can be distinguished from that of $C$. distortus by having three elements (instead of two) on the accessory antennule, by the presence of a medial knob on the labrum and by having three setae on the caudal ramus.

Capart (1959) reported C. zei on Z. conchifer from eastern Atlantic off the coasts of Angola. This species can be easily differentiated from the new species by having numerous outgrowths in the form of processes, the head devoid of processes and discoid egg sacs.

This is the third record of a member of Chondracanthus in waters off Argentina, following the previous records of C. genypteri (Thomson, 1890) from Genypterus bla- 


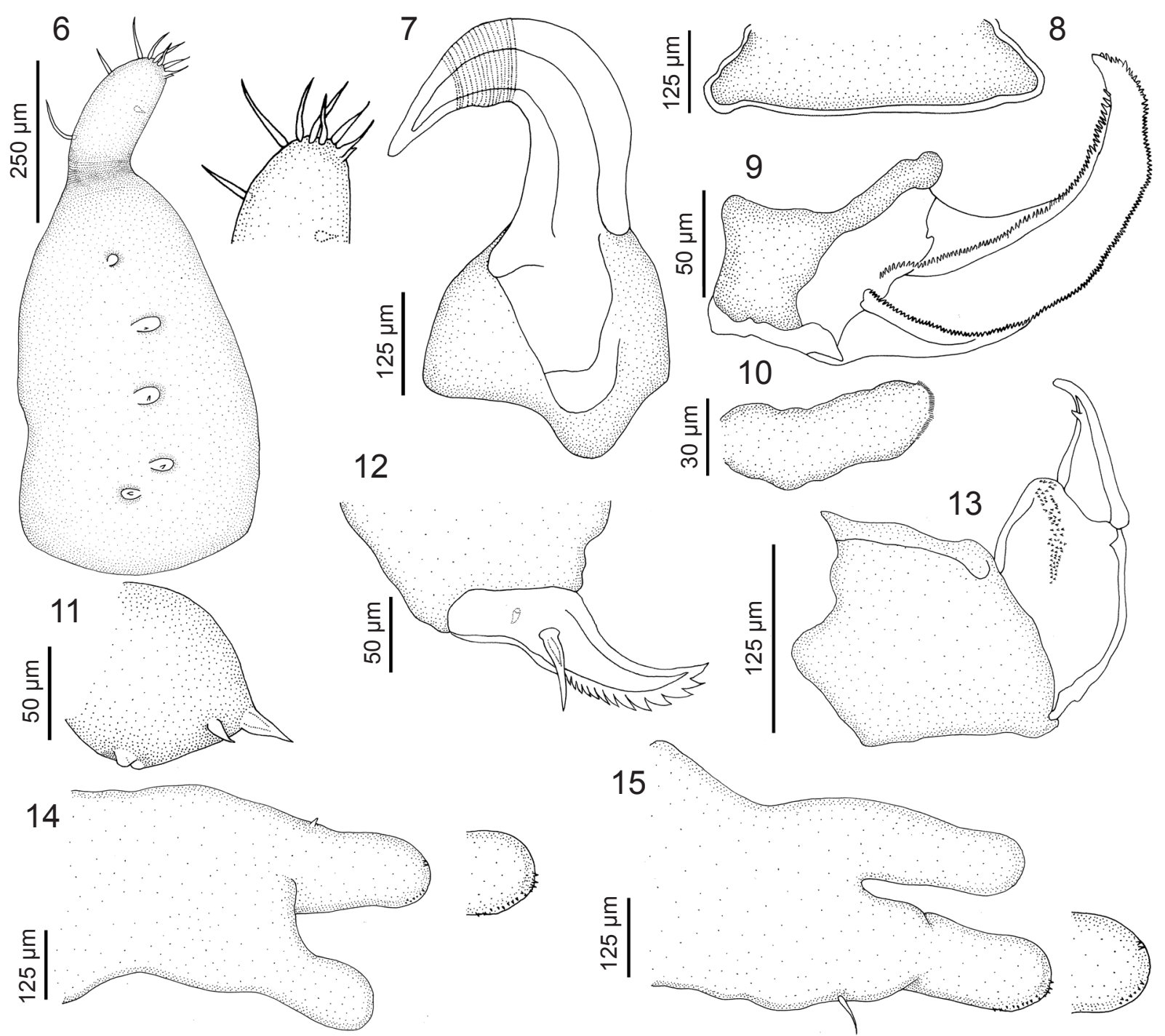

Figs. 6-15. Chondracanthus hoi sp. n., female. Fig. 6. Antennule. Fig. 7. Antenna. Fig. 8. Labrum. Fig. 9. Mandible. Fig. 10. Paragnath. Fig. 11. Maxillule. Fig. 12. Maxilla. Fig. 13. Maxilliped. Fig. 14. Leg 1. Fig. 15. Leg 2.

codes Schneider (see Etchegoin and Sardella 1989) and C. australis Ho, 1991 from Merluccius hubbsi Marini (see Etchegoin et al. 1997). The new species also represents the first record of a chondracanthid parasitizing a zeiform fish in South American waters and the second species of the genus found in $Z$. conchifer.

The absence of zeid fishes other than $Z$. conchifer in South American Atlantic waters could indicate that this fish is the principal host for the new species. However, its presence on other zeiform species in the region cannot be disregarded, because representatives of the families Oreosomatidae, Parazenidae and Zenionidae inhabit the same region (Froese and Pauly 2012). In fact, host-switching of chondracanthids between zeiforms of different families has been recorded for $C$. distortus (Ho 1975).

However, this fact remained unnoticed because Ho (1975) reported its presence in a host listed as Cottus novaezealandiae, which represents undoubtedly a typo- graphic error because this specific name does not exist in the genus Cottus Linnaeus (Cottidae), whereas the zeiform Cyttus novaezealandiae (Arthur) (Cyttidae) inhabits New Zealand waters (Froese and Pauly 2012); relatedness of cyttids with zeids makes the finding of $C$. distortus on $C$. novezelandiadae less questionable.

The record of C. zei on Z. conchifer from Angola (Capart 1959) may also represent a host-switching event, with the acquisition of the parasite from $Z$. faber (Zeidae) living sympatrically with $Z$. conchifer in this region, the latter fish being unique host of $C$. zei in European waters (Ho 1970, Kabata 1979). Chondracanthus zei has an intriguing geographical distribution, being one of the two species in the genus known from the Atlantic and Pacific oceans (Ho 1991), and parasitizing Z. faber in the Sea of Japan (Ho 1970), whereas the same host shares $C$. distortus with Z. nebulosa on the Pacific coasts of Japan (Wilson 1922, Yamaguti 1939, Shiino 1955, Ho 1991). 

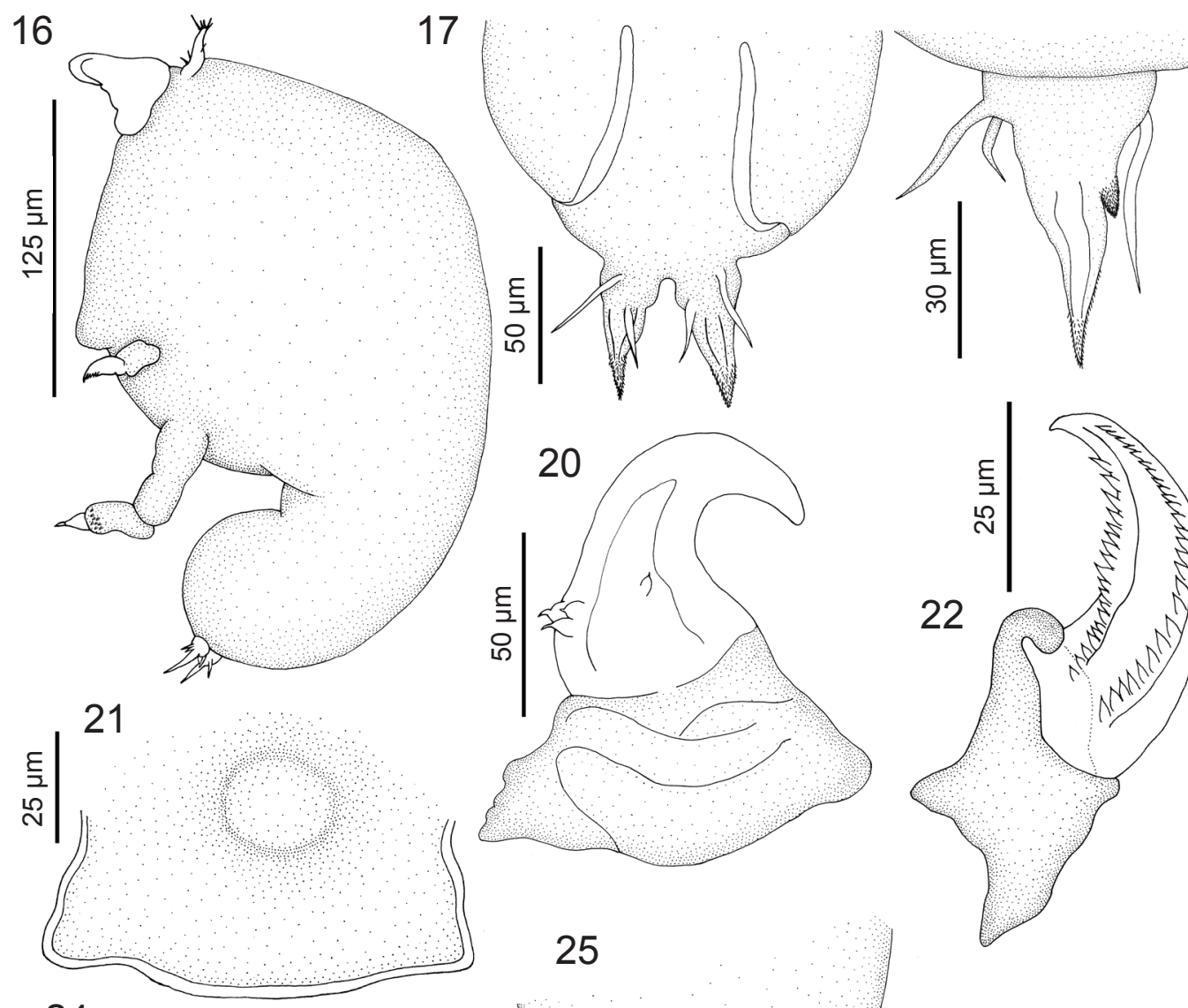

18
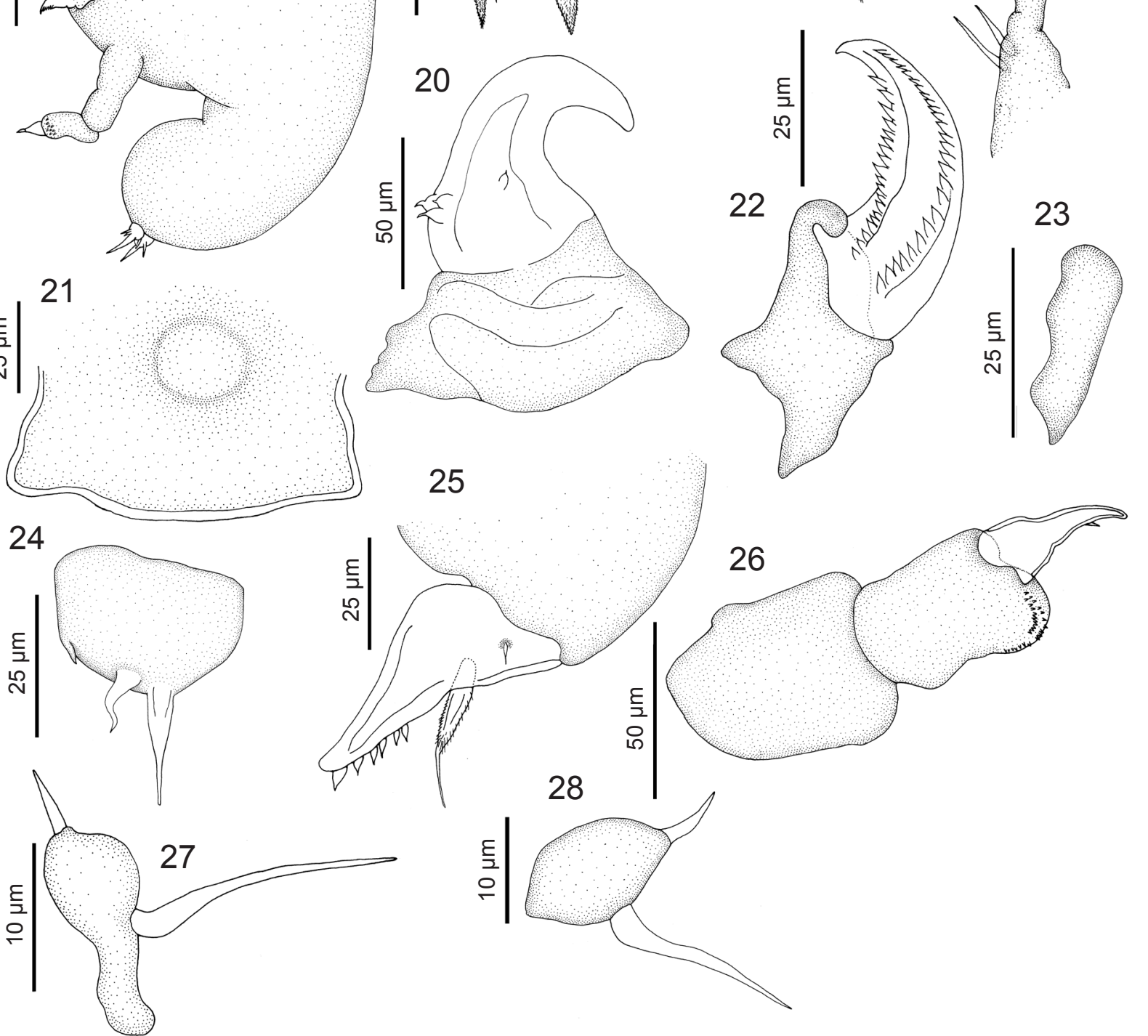

5
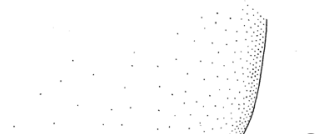
A further problem for the assessment of the phylogenetic relationships between these copepods, as well as of their co-evolutionary history with their hosts, comes from a series of inconsistencies in the literature. After the redescription of $C$. distotus from 'Cottus' novaezealandiae by Ho (1975), this species was reported in fishes of two families of two different orders, namely Zeidae (Zeiformes) and Cottidae (Scorpaeniformes), in the hostparasite list provided by Ho (1991) for the genus Chondracanthus. In the same list, Z. faber was omitted as the host of C. zei.

Subsequently, the host-parasite list by Ho (1991) was used for a coevolutionary study between chondracanthids and their hosts (Paterson and Poulin 1999), showing that in Zeiformes, Chondracanthus spp. and their fish hosts have co-evolved, a logical result given the morphological similarity between these copepod species (Ho 1991).
However, co-evolution of these copepods with their fish hosts of the order Zeiformes should be studied in more detail considering the new findings, as well as the hostparasite relationships omitted previously. For example, C. zei is only reported in the genus Zenopsis (as Zenopis), in which it has been recorded once (Capart 1959), but not in the genus Zeus, where most copepods of this species have been registered in a wide geographic range. Furthermore, the presence of $C$. distortus in fishes other than Zeiformes was not discussed in the paper by Paterson and Poulin (1999). However, the identity of these hosts as Zeiformes instead of Scorpaeniform requires new analyses on the specificity of chondracanthids of dories and their co-evolutionary relationships.

Acknowledgements. Financial support was provided by grants from CONICET (PIP 112-200801-00024) and Universidad Nacional de Mar del Plata (EXA 621/12).

\section{REFERENCES}

Bush A.O., Lafferty K.D., Lotz J.M., Shostak A.W. 1997: Parasitology meets ecology on its own terms: Margolis et al. revisited. J. Parasitol. 83: 575-583.

CAPART A. 1959: Copépodes parasites: résultats scientifiques de l'expédition océanographique belge dans les eaux côtieres africaines de l'Atlantique Sud (1948-1949). Inst. Roy. Sci. Nat. Belgique 3: 55-126.

Etchegoin J.A., Sardella N.H. 1989: Registro de la presencia y consideraciones ecológicas preliminares de Chondracanthus genypteri Thomson, 1889 (Copepoda: Chondracanthidae) parásito de Genypterus blacodes en Argentina. Parasitol. Día 13: 88-89.

Etchegoin J.A., Sardella N.H., Timi J.T. 1997: Clarification of the identity of copepods of the genus Chondracanthus parasitizing Merluccius hubbsi from Argentinean waters. J. Parasitol. 83: $155-158$.

Froese R., Pauly D. (Eds.) 2012: FishBase. World Wide Web electronic publication. Www.fishbase.org, 12/2012.

Haimovici M., Silva Marins A., Lima de Figueiredo J., CasTELli Vieira P. 1994: Demersal bony fish of the outer shelf and upper slope of the southern Brazil Subtropical Convergence Ecosystem. Mar. Ecol. Prog. Ser. 108: 59-77.

Ho J.S. 1970: Revision of the genera of the Chondracanthidae, a copepod family parasitic on marine fishes. Beaufortia 229: $105-218$

Ho J.S. 1975: Cyclopid copepods of the family Chondrcanthidae parasitic on New Zealand marine fishes. Pub. Seto Mar. Biol. Lab. 22: 303-319.

Ho J.S. 1991: Redescription of Chondracanthus zei Delaroche (Copepoda, Poecilostomatoida) parasitic on Zeus faber L. in

Received 5 January 2013 the Sea of Japan, with a preliminary review of the genus. Rep. Sado Mar. Biol. Stat., Niigata Univ. 21: 49-79.

Kabata Z.1979: Parasitic Copepoda of British fishes. The Ray Society, London, 468 pp.

Nakabo T., Bray D.J, Yamada U. 2006: A new species of Zenopsis (Zeiformes: Zeidae) from the South China Sea, East China Sea and off Western Australia. Mem. Mus. Victoria 63: 91-96.

Paterson A.M., Poulin R. 1999: Have chondracanthid copepods co-speciated with their teleost hosts? Syst. Parasitol. 44: 79-85.

Quigley D.T.G., Flannery K. 1995: Sailfin dory Zenopsis conchifer (Lowe 1852): further records from Irish waters and a review of north-west European records. Ir. Nat. J. 25: 71-76.

Santini F., Tyler J.C., Alexandre F., Bannikov A.F, Baciu D.S. 2006: A phylogeny of extant and fossil buckler dory fishes, family Zeidae (Zeiformes, Acanthomorpha). Cybium 30: 99-107.

Scotт W.B., Scotт M.G. 1988: Atlantic fishes of Canada. Can. Bull. Fish. Aquat. Sc. 219: 1-731.

ShinNo S.M. 1955: Copepods parasitic on Japanese fishes. 9. Family Chondracanthidae, Subfamily Chondracanthinae. Rep. Fac. Fish. Pref. Un. Mie. 2: 70-111.

TAng D., Andrews M., Cobcroft J.M. 2007: The first chondracanthid (Copepoda: Cyclopoida) reported from cultured finfish, with a revised key to the species of Chondracanthus. J. Parasitol. 93: 788-795.

Wilson C.B. 1922: Parasitic copepods from Japan, including five new species. Ark. Zool. 14: 1-17.

Yamaguti S. 1939: Parasitic copepods from fishes of Japan. Part 6. Lernaeopodida I. Vol. Jub. Prof. Sadao Yoshida. 2: 529-578.

Accepted 7 April 2013 